\title{
The effect of age on semen freezability of Swamp Buffalo bull in a commercial artificial insemination center
}

\author{
Nurul Isnaini ${ }^{1 *)}$, Tri Harsi $^{2)}$ and Wahyu Riza Zamani ${ }^{1)}$ \\ ${ }^{1)}$ Department of Animal Production, Faculty of Animal Science, University of Brawijaya, Jl. \\ Veteran, Malang 65145, Indonesia \\ ${ }^{2)}$ Lembang Artificial Insemination Center, J1. Kayu Ambon, Bandung 40391, Indonesia
}

Submitted: 08 September 2019, Accepted: 01 December 2019

\begin{abstract}
This study aimed to assess the effect of age on semen freezability (sperms motility before freezing, post-thawing, recovery rate, and straws production per ejaculate) of swamp buffalo bull kept in Lembang Artificial Insemination Center. A total of 115 ejaculates collected from one swamp buffalo bull at 5, 6 and 7 years old were included in the study. The results showed that the overall mean values of sperms motility before freezing, post-thawing, recovery rate, and straws production per ejaculate of swamp buffalo bull were $62.13 \%, 43.61 \%, 62.16 \%$, and 114.16 doses, respectively. The age of bull did not show significant $(\mathrm{P}>0.05)$ effect on sperms motility before freezing, however the sperms motility post-thawing, recovery rate, and straws production per ejaculate was influenced $(\mathrm{P}<0.01)$ by bull age. At seven years old, the poorest $(\mathrm{P}<0.01)$ post-thawing sperms motility and recovery rate were noted in comparison to 5 and 6 years old, nevertheless the difference in post-thawing sperms motility was only less than $3 \%$ point, which was not biologically important. On the other hand, the semen collection at seven years old had a higher $(\mathrm{P}<0.01)$ straws production per ejaculate than those at 5 and 6 years old (133.70 vs. 106.39 and 90.61 doses, respectively). In conclusion, this study provides evidence that the semen freezability of swamp buffalo bull is varied among the age with the peak frozen semen production was achieved at seven years old.
\end{abstract}

Keywords: artificial insemination; Bubalus bubalis; bull age; sperms motility; frozen semen production.

*Corresponding Author: nurulisna@ub.ac.id 


\section{INTRODUCTION}

The rapid population growth, along with the improvement in education level and economic status, has driven the increase in Indonesian national meat demand. In 2017, it was reported that the national meat consumption reached about 7.90 $\mathrm{kg} /$ capita/year (Directorate General of Livestock and Animal Health, 2018), which was $84.15 \%$ higher than national meat consumption in 2009 with 4.29 $\mathrm{kg} /$ capita/year (Directorate General of Livestock and Animal Health, 2014). Besides, it was predicted that national meat consumption would be further increased in the future with the growth rate of $6.30 \%$ per year (Central Data and Information System of Agriculture, 2017).

Swamp buffalo is one of the livestock commodities, which is very potential to support the fulfillment of national meat demand. Buffalo has great adaptability to the tropical environment (Deka et al., 2019) and also has good capability to convert low quality feed from agriculture by-product into valuable food (Naveena and Kiran, 2014). However, the buffalo population remained stable in the last decade. The buffalo population in 2011 was 1.31 million head (Directorate General of Livestock and Animal Health, 2014), while in 2018 become 1.36 million head (Directorate General of Livestock and Animal Health, 2018). This fact, probably due to the lower reproductive efficiency in swamp buffalo. For that reason, the application of reproductive technology is highly demanded to improve the buffalo population.

Artificial insemination is a leading reproductive technology which widely used to improve reproductive efficiency and genetic quality of livestock. Several advantages of this technology allow the production of crossbred livestock, which have high adaptability to the local climate and could increase the performance and uniformity of offspring (Baruselli et al.,
2018). However, the benefit of artificial insemination can only be achieved when supported by good semen quality (Islam et al., 2018). Numerous factors such as age, breed, nutrition, and environmental condition have been well documented, influencing semen quality of bull (Bhakat $e t$ al., 2011; Kumar et al., 2017; Murphy et al., 2018). In cattle, the age was recognized as the critical factor affecting semen quality since it determining the reproductive physiology of bull (Snoj et al., 2013; Isnaini et al., 2019a). While in buffalo, the study regarding the effect of age on semen quality is still very scanty. Therefore, this study was performed to evaluate the effect of age on semen freezability of a swamp buffalo bull.

\section{MATERIALS AND METHODS Geographical location}

This study was conducted in Lembang Artificial Insemination Center, Bandung, West Java, Indonesia. The latitudelongitude coordinates and altitude of this site are approximately $6^{\circ}$ South $-107^{\circ}$ East and 1,241 $\mathrm{m}$ above sea level, respectively.

\section{Experimental animal}

The experimental animal used in this study was one healthy swamp buffalo bull. The bull was reared in an individual pen (4 x $2.5 \mathrm{~m}$ ). During the experimental period, the bull received ad libitum access to drinking water and fed according to the standard protocol in Lembang Artificial Insemination Center, as shown in Table 1.

\section{Semen evaluation}

A total of 115 ejaculates were collected at 5, 6, and 7 years old $(46,23$, and 46 ejaculates, respectively). Sperms motility before freezing and post-thawing were evaluated under a microscope with $400 \times$ magnification (Susilawati et al., 2018). Recovery rate value was calculated by a formula of $=$ (sperms motility postthawing / individual sperms motility) $\mathrm{x}$ 100\% (Isnaini et al., 2019b). Straws production per ejaculate was calculated by a formula of $=$ total sperm number per 
ejaculate / 25 million sperm (Isnaini et al., 2019b).

\section{Statistical analysis}

Data of semen freezability were analyzed using analysis of variance followed by Duncan test to separate means. The effect of age was considered as significant and highly significant differences when $\mathrm{P}<0.05$ and $\mathrm{P}<0.01$, respectively.

Table 1. Feed composition during the experimental period

\begin{tabular}{lc}
\hline Ingredient & Amount per day (as fed) \\
\hline Elephant grass & $65 \mathrm{~kg}$ \\
Concentrate feed & $4 \mathrm{~kg}$ \\
Hay & $1 \mathrm{~kg}$ \\
Mung bean sprout & $0.5 \mathrm{~kg}$ \\
\hline
\end{tabular}

\section{RESULTS AND DISCUSSION}

The results of this study showed that the overall mean values of sperms motility before freezing, post-thawing, recovery rate, and straws production per ejaculate of swamp buffalo bull were $62.13 \%, 43.61 \%$, $62.16 \%$, and 114.16 doses, respectively. Previously, Amin et al. (1999) showed that sperms motility post-thawing of swamp buffalo bulls ranged from 41.43 to $55.71 \%$. In another study, Ahmed et al. (2018) found that sperms motility post-thawing of NiliRavi buffalo bulls was between 43.80 to $46.60 \%$.

The straws production per ejaculate of buffalo bull obtained in this study was 52 to $60 \%$ lower than elite beef cattle (Isnaini $e t$ al., 2019a). Table 2 shows that the age of bull did not show significant $(\mathrm{P}>0.05)$ effect on sperms motility before freezing, however sperms motility post-thawing, and recovery rate were influenced $(\mathrm{P}<0.01)$ by bull age.
At 7 years old, swamp buffalo bull had the poorest $(\mathrm{P}<0.01)$ sperms motility postthawing and recovery rate compared to 5 and 6 years old. In line with this finding, Ahmed et al. (2018) also found that aged buffalo bulls had lower sperms motility post-thawing than the young bulls. In other livestock such as dairy cattle, it was also reported that the bull age had a significant effect on sperms motility post-thawing (Murphy et al., 2018).

This result probably because of the advancing age had a negative impact on the concentration of antioxidant substances in seminal plasma (El Sisy et al., 2016), which then may result in the reduction of sperms motility after cryopreservation. Nevertheless, the difference in sperms motility post-thawing between 7 years old vs. 5 and 6 years old was not more than $3 \%$ point, which could be categorized as not biologically important.

Table 2. Effect of age on semen freezability of swamp buffalo bull

\begin{tabular}{lccc}
\hline \multirow{2}{*}{ Parameters } & \multicolumn{3}{c}{ Bull age } \\
\cline { 2 - 4 } & 5 yo $(\mathrm{n}=46)$ & 6 yo $(\mathrm{n}=23)$ & 7 yo $(\mathrm{n}=46)$ \\
\hline SMBF $(\%)$ & $61.96 \pm 2.47$ & $62.17 \pm 2.53$ & $62.28 \pm 2.52$ \\
SMPT (\%) & $44.89 \pm 4.28^{\mathrm{b}}$ & $44.35 \pm 4.84^{\mathrm{b}}$ & $41.96 \pm 4.01^{\mathrm{a}}$ \\
RR $(\%)$ & $63.87 \pm 6.38^{\mathrm{b}}$ & $63.35 \pm 6.91^{\mathrm{b}}$ & $59.86 \pm 5.80^{\mathrm{a}}$ \\
SPPE (doses) & $106.39 \pm 43.40^{\mathrm{b}}$ & $90.61 \pm 37.20^{\mathrm{a}}$ & $133.70 \pm 36.73^{\mathrm{c}}$ \\
\hline
\end{tabular}

yo = years old, $\mathrm{SMBF}=$ sperms motility before freezing, SMPT = sperms motility post-thawing, $\mathrm{RR}=$ recovery rate, $\mathrm{SPPE}=$ straws production per ejaculate

${ }^{\mathrm{a}-\mathrm{c}}$ different superscript indicates a highly significant difference $(\mathrm{P}<0.01)$ 
As shown in Table 2, straws production per ejaculate varied $(\mathrm{P}<0.01)$ among bull age. The semen collection at 7 years old had a higher $(\mathrm{P}<0.01)$ straws production per ejaculate than those at 5 and 6 years old. This result probably could be partly explained by the improvement of reproductive organ development as the age getting older (Pant et al., 2003), which may increase sperms production capacity, thus providing higher frozen semen production.

\section{CONCLUSION}

According to the results in this current study, it can be concluded that the variation on semen freezability of swamp buffalo bull exists among the age. The semen collection at 7 years old provides preferable frozen semen production but with slightly lower sperms motility aspect compared to 5 and 6 years old.

\section{ACKNOWLEDGMENT}

The authors have gratefully acknowledged the research facility provided by Lembang Artificial Insemination Center.

\section{REFFERENCES}

Ahmed, S., Khan, M. I. ur R., Ahmad, M., and Iqbal, S. (2018). Effect of age on lipid peroxidation of fresh and frozenthawed semen of Nili-Ravi buffalo bulls. Italian Journal of Animal Science, 17(3), 730-735. https://doi.o rg/10.1080/1828051X.2018.1424569

Amin, M. R., Toelihere, M. R., Yusuf, T. L., and Situmorang, P. (1999). Pengaruh plasma semen sapi terhadap kualitas semen beku kerbau lumpur (Bubalus bubalis) (in Bahasa Indonesia). Jurnal Ilmu Ternak Dan Veteriner, 4, 143-147.

Baruselli, P. S., Ferreira, R. M., Sá Filho, M. F., and Bó, G. A. (2018, June 1). Review: Using artificial insemination v. natural service in beef herds. Animal. Cambridge University Press. https://doi.org/10.1017/S1751731118 00054X
Bhakat, M., Mohanty, T. K., Raina, V. S., Gupta, A. K., Khan, H. M., Mahapatra, R. K., and Sarkar, M. (2011). Effect of age and season on semen quality parameters in Sahiwal bulls. Tropical Animal Health and Production, 43(6), 1161-1168. https: //doi.org/10.1007/s11250-011-9817-1

Central Data and Information System of Agriculture. (2017). Outlook Daging Sapi (in Bahasa Indonesia). Jakarta: Ministry of Agriculture Republic of Indonesia.

Deka, R., Nath, K. C., Bhuyan, M., Bhuyan, D., Das, G. C., Dutta, L., and Borpujari, D. (2019). Parturition behavior of Swamp buffalo cows (Bubalus bubalis) under organized system of rearing. Biological Rhythm Research. https://doi.org/10.1080/092 91016.2019.1607220

Directorate General of Livestock and Animal Health. (2014). Livestock and Animal Health Statistics. Jakarta: Ministry of Agriculture Republic of Indonesia.

Directorate General of Livestock and Animal Health. (2018). Livestock and Animal Health Statistics. Jakarta: Ministry of Agriculture Republic of Indonesia.

El Sisy, G. A., Abo El-Maaty, A. M., and Rawash, Z. M. (2016). Comparative blood and seminal plasma oxidant/antioxidant status of Arab stallions with different ages and their relation to semen quality. Asian Pacific Journal of Reproduction, 5(5), 428-433. https://doi.org/10.1016/j.ap jr.2016.07.006

Islam, M., Apu, A., Hoque, S. A., Ali, M., and Karmaker, S. (2018). Comparative study on the libido, semen quality and fertility of Brahman cross, Holstein Friesian cross and Red Chittagong breeding bulls. Bangladesh Journal of Animal Science, 47(2), 61-67. https://doi.org/ 
10.3329/bjas.v47i2.40236

Isnaini, N., Wahjuningsih, S., and Adhitama, E. (2019). Seasonal effects on semen quality of Ongole crossbred and Simmental bulls used for artificial insemination. Livestock Research for Rural Development.

Isnaini, N., Wahjuningsih, S., Ma'ruf, A., and Witayanto, D. A. (2019). Effects of age and breed on semen quality of beef bull sires in an Indonesian artificial insemination center. Livestock Research for Rural Development.

Kumar, A., Singh, P., Bhakat, M., Singh, S., Nitharwal, K., and Gupta, A. K. (2017). Effect of feed energy levels on semen quality and freezability of young murrah buffalo bulls. Buffalo Bulletin, 36(2), 415-426.

Murphy, E. M., Kelly, A. K., O’Meara, C., Eivers, B., Lonergan, P., and Fair, S. (2018). Influence of bull age, ejaculate number, and season of collection on semen production and sperm motility parameters in holstein friesian bulls in a commercial artificial insemination centre. Journal of Animal Science, 96(6), 2408-2418. https://doi.org/10.1093/jas/sky130
Naveena, B. M., and Kiran, M. (2014). Buffalo meat quality, composition, and processing characteristics: Contribution to the global economy and nutritional security. Animal Frontiers, 4(4), 18-24. https://doi. org/10.2527/af.2014-0029

Pant, H. C., Sharma, R. K., Patel, S. H., Shukla, H. R., Mittal, A. K., Kasiraj, R., Prabhakar, J. H. (2003). Testicular development and its relationship to semen production in Murrah buffalo bulls. Theriogenology, 60(1), 27-34. https://doi.org/10.1016/S0093-691X( 02)01037-3

Snoj, T., Kobal, S., and Majdic, G. (2013). Effects of season, Age, And breed on semen characteristics in different Bos taurus breeds in a 31-year retrospective study. Theriogenology, 79(5), 847-852. https://doi.org/10.10 16/j.theriogenology.2012.12.014

Susilawati, T., Ratnawati, D., Isnaini, N., Kuswati, K., and Yekti, A. P. (2018). Character of liquid semen motility in various diluents on Balinese cattle during cold storage. Asian Journal of Microbiology, Biotechnology and Environmental Sciences, 20(1), 166172. 